\title{
What Expert Say about Empowering Human Resources in Supporting Leadership Function in Higher Education in the 21st Century
}

\author{
Eric Hermawan1, Antoni Ludfi Arifin² \\ 1Universitas Negeri Jakarta, Indonesia \\ 2Institut Ilmu Sosial dan Manajemen STIAMI, Indonesia \\ ludfi@stiami.ac.id
}

\section{ARTICLE INFO \\ Article history: \\ Received \\ April 13, 2021 \\ Revised \\ 08 June, 2021 \\ Accepted \\ July 11, 2021}

\begin{abstract}
In Indonesia, universities and non-formal education institutions play an essential role in creating leadership qualities in both colonial and modern time. Although these two education models have different supports, the resulting figures are expected to be involved in community development with intervention through research and community service with the budget and recognition given to them. This qualitative study was going to understand what research evidence says about the leadership role in higher education. To ascertain how these educational institutions' involvement and role are. The researchers have conducted electronic searches on online data sources such as the Google Scholar application, ERIC Publications, and Microsoft Academic for publications from 2010 to 2021. Furthermore, analyzing the data by involving understanding the problem, coding the data. Evaluation and in-depth interpretation to obtain valid and reliable findings. Based on the discussion of the findings data and previous research evidence, the researchers reported the results, the transition period to a more advanced future, and higher education's role in more strategic and dynamic planning. Higher education leaders must work to foster the public by encouraging lecturers and faculty with study data and dedication to achieve development goals towards success. They take great responsibility for the success of nation-building in all directions. Thus, these findings become an essential input in developing the role of higher education leadership.
\end{abstract}

ABSTRACT

Keywords: Empowering Human Research, Leadership Function, Higher Education

How to cite Hermawan, E., \& Arifin, A., (2021). What Expert Say about Empowering Human Resources in Supporting Leadership Function in Higher Education in the 21st Century. Jurnal Iqra' : Kajian Ilmu Pendidikan, 6(2). 27-38. https://doi.org/10.25217/ji.v6i2.1493

Journal Homepage http://journal.iaimnumetrolampung.ac.id/index.php/ji/

This is an open access article under the CC BY SA license

https://creativecommons.org/licenses/by-sa/4.0/

\section{INTRODUCTION}

A prosperous country is a country that has quality human resources and can compete with other countries. (Council, 2012; Malik, 2013). One of the most critical institutions in improving the quality of human resources in higher education. (Siemens et.al, 2013). So that universities must make dynamic adjustments to the development of the future. One form of adjustment effort is to listen to the opinions and thoughts of experts about efforts to improve human resources through higher education, which is an institution that prepares superior human resources and can apply their knowledge and expertise in the development of state progress which has three main pillars, 
namely increasing competitiveness: freedom, independence of human resources, and socio-economic welfare. (Pieper, 2012; Wächter, 1991).

The higher education has two missions, namely improving the quality and quantity of human resources. This means producing a large number of qualified human beings so that they will later become the support for the country's continuity and the development of world peace. Christensen \& Eyring, (2011) who said that universities have a role that is ready to innovate changes in human resources' DNA. In other words, the task of higher education is to produce creative, highly competitive, and productive people. Higher education also fosters and educates students to become intelligent human resources to play a role and contribute to development following their respective positions and abilities. (Conley \& Smith, 2013). This quality improvement is so significant that its development requires serious attention from all parties.

To function like the public's expectations, universities must face challenges and opportunities to handle professionals who have proven their abilities. They are human resources prepared to manage and improve the quality of higher education output. (Council, 2012). The expected output is such as lecturers and alumni who are ready to contribute to making changes. Of course, educational personnel such as teaching staff are the central point of higher education institutions and administrative staff and student organizations. For example, as Sewell \& Kingsley, (2017) said, ready-to-use personnel is ready to develop 21st-century professionals. Due to the quality and commitment of teaching staff who are supported by adequate facilities and infrastructure and a conducive environment, it will provide exceptional satisfaction for lecturers, and This is the primary key to the success of a university in addition to the support of adequate asset and infrastructure resources. (Lewin \& McNicol, 2015). In this way, can universities improve the quality of human resources? The answer with human resources and national character, education will undoubtedly color the development of the Indonesian nation.

According to Law Number 12 of 2012 concerning Higher Education. (UndangUndang Republik Indonesia, 2012), this regulation characterizes that further education is an effort to increase human resources that require professionalism to support the community, nation, and state. Meanwhile, Human Resources is an integrated ability of one's thinking and physical power. With the Higher Education Law's authority, higher education managers have the mandate to produce ready-to-use human resources. (Lestari, 2018). This indicates that the power of innovation is the intelligence that is born while the ability is obtained from educational efforts. Physical strength is the strength and resistance of a person to do a job or carry out a task assigned to him. Thus, as Bafadal et al., (2019) said, human resources in education are functional competencies possessed by educational staff in carrying out their duties. With essential competencies and teaching leadership, investment can innovate human resources into personnel ready to develop other human resources.

The nation's progress is very much influenced by education, where the educational factor will differentiate the fate of their life and welfare. Because education and progress are closely related to each other, the solution must go together. The two of them have a relationship that affects each other. In this case, development can be carried out through education as a vehicle for development. Thus (Garavan, 2007), education requires competent human resources as assets of the development process, and competent human resources are achieved through the development process. Therefore, Tyas et al., (2020) believe that human resources are part of development and 
education. The required quality human resources are obtained through a process so that education and training programs are needed to prepare and develop human resources quality after the occurrence of social transformation.

Talking about the proper education for the Indonesian context is indeed very complex. Giambatista et al., (2017) noted that the new generation and development in learning require solutions to overcome complexity in an increasingly competitive era. Education is an ethical endeavor for humans, for humans, and human society. Education can develop one's talents to an optimal level within the limits of individual nature, with the aim that every human being can participate in an honorable role in human development and society continues to achieve a higher dignity. Education is a light that guides humans in determining the direction, purpose, and meaning of life.

At first glance, several years earlier, Indonesia had an outstanding and extraordinary national figure as national famous people. He is a figure who has contributed totally to the advancement of science and innovation, both in our beloved country Indonesia and in the planetary field. He has an extraordinary vocation as an innovator of the aviation hypothesis but in the splendor of a national figure, which indicates the HR framework's achievement in Indonesia? Schools in Indonesia are not comparable to the professions of some of these figures. The UNESCO world institution of education and culture acknowledges that education's quality is still very concerning. (Pazli \& Sahputra, 2014). They added that the role of UNESCO in eradicating illiteracy in Indonesia 2007-2012 was very high.

Moreover, DAN (2020) noticed that the language advancement and improvement office of the Ministry of Education and Culture of the Ministry of Education and Culture shows that among the 1.6 million individuals from the instructor competency test, more than 1.3 million of them have a score under 60 of value inclusion of 0 to 100 . From this test, as well, just 192 teachers scored more than 90. All the while, almost 130 thousand of them are prepared to score under 30. What low the limit concerning preparing will mean for the idea of the school in every district. Likewise, Indonesia's structure of preparing or instructive projects are evolving occupy. (Tanang \& Abu, 2014). Since actually, public specialists frequently go to new instructive designs to improve the idea of Indonesia's tutoring. At times, in any case, public organizations' points in improving preparation by and large do not coordinate with reality on the ground.

Moreover, Indonesia has many instructive issues that emerge from the educational plan, quality, ability, and even authority skills both at the top and underneath levels, as referenced above. (Steiner, 2010; Aslan et al., 2020; Aslan, 2017). Since training is the way to public turn of events, the instructive initiative is indispensable in coordinating and carrying out schooling strategy. It should be conceded that training is perhaps the most moving issue to confront. (Churiyah dkk., 2020). Different sorts of approaches have been completed by the public authority, albeit they digress from the arrangements. Researchers should not censure the public authority for the lousy quality of schooling in Indonesia and understand that the advancement of instruction is the obligation, everything being equal (Riddell \& NiñoZarazúa, 2016). The researchers must be thoughtful, do not ask what we got from the instruction framework; however, ask ourselves which commitment we have made to help the public authority propel the nature of Indonesia's schooling.

The essential thing that should be taken into account by the Indonesian nation, especially the Indonesian government, is how to make a country with a large population superior in the quality of its human resources. Thus the biggest challenge of 
this nation is the low quality of education. This nation inevitably has to make improvements and reforms in various sectors related to education. Regarding the prospects for national education in the face of the era of globalization, global awareness about increasing human resources is a must for the world of education. This is because education is a form of investment in preparing the quality of quality Indonesian human resources. (Fowler, 2018).

Improving the quality of superior and quality human resources from higher education institutions certainly requires strategies that need to be carried out. The strategies that can be carried out include the first, namely, lecturers as teachers and educators. Lecturers must have the qualifications needed to impart their knowledge to students. With competent and qualified lecturers, it will facilitate the delivery of science and technology so that what is conveyed to students can be accepted and developed according to the students' abilities with the study of their chosen field of study. (White, 2012).

In addition, efforts are needed to improve the quality of existing lecturers; fundamental changes to the curriculum and teaching and learning methods will be imbalanced and less effective. Improving the quality of lecturers needs to start from the recruiting system, increasing lecturers' ability, a system for assessing the abilities and performance of lecturers, and a system for advancing their careers. Of course, efforts to improve the quality of lecturers need to be accompanied by an increase in their welfare. (Hanapi \& Nordin, 2014). The lecturers' abilities include the ability in science to be taught and techniques in providing teaching. This means that increasing the ability of lecturers needs to be carried out lecturers quality increasing knowledge in their fields, and the ability or skills in teaching, namely using appropriate learning methods.

It can also be done by increasing local, regional, and national seminar activities, symposiums, discussions, and upgrades, and workshops, both at the faculties and universities themselves and at leading universities in the country. (Thomas dkk., 2010). They are increasing cooperation activities with government agencies, the business world, and the industrial world about linkage and equivalence programs as an addition to insight and ways of thinking as well as skills for lecturers. With the synergy between the government, universities, and the world of business / industry, the imbalance in college graduates' quality is a responsibility that must be shared. The government provides guidance and regulation functions; the business/industry graduates and universities prepare their graduates with standardized quality to business/industry.

The second strategy is in terms of students. This strategy is carried out by selecting prospective students. In some higher education institutions usually make targets in accommodating as many students as possible. (Kakuma dkk., 2011). Admission of as many prospective students without conducting a selection test, the prospective students' quality is still questionable. Whether the prospective students have met the quality standards set, for this reason, there is a need for a selection system that will produce quality students. In improving the quality of education, prospective students must be selected by rigorous selection so that the accepted prospective students have good quality standards because, after all, students have responsibility for the development of a university.

The third strategy is in terms of facilities and infrastructure. It is necessary to produce quality higher education graduates to cooperate with the business/industry as absorbers and users of university graduates. (Norton, 2008). This can be done by 
involving students, alumni, and companies representing the business world to provide helpful input to produce college graduates who are expected to participate in the era of globalization. It is necessary to improve the curriculum by adding new programs such as mastery of international languages, computer technology, internships, and ethics. The laboratory as a place for student training and practice needs to be equipped with adequate facilities, and its training program must be adjusted to the development of the industrial and service world.

Meanwhile, as the heart of higher education, the library needs to be enriched and equipped with the latest journals and literature. Complete computerized facilities and tools allow students to interact globally, including exploring knowledge via the internet. Likewise, the building or lecture room and its equipment to support the education and teaching process need attention regarding cleanliness, beauty, and comfort. As a result of this gap between what univeresity do to improve outputs quality and what public learning and graduate outcomes they need. To fulfill this problem, the researchers would like to search and understand what preview study evidence is relevant to advice all parties.

\section{METHODS}

Our study wants to understand what experts say about human resource empowerment in supporting leadership functions in tertiary institutions in the 21st century. Indonesia has made higher education institutions play an essential role in producing superior community leadership. Even so, these educational institutions have not yet functioned as higher education institutions in charging public leaders with budget and attention so that higher education figures produce excellent human resources through studies, teaching, and public service. To understand the extent of involvement and role of higher education. The researchers conducted research electronically on online data; Google Scholar application, ERIC Publications, Microsoft Academic published from 2010 to 2021. The data is then extracted, analyzed with a coding system, evaluation, and in-depth interpretation until The researchers find valid and reliable data. The researchers studied came from secondary data through descriptive qualitative reporting. In all stages, The researchers follow a systematic review qualitative review guide such as Kirkwood \& Price, (2014).

\section{RESULT AND DISCUSSION}

Understand how to empower human resources in supporting leadership functions in the future higher education level according to Lozano et al., (2013) who stated that universities must be able to produce future leaders and the locomotive of changing times. They added that universities must be able to understand the needs of society in a more challenging future. For this reason, the existence of higher education and its expert staff must be increased in actualization by applying a modern paradigm. Besides, universities can ensure that human resources are the golden asset of all the core goals of higher education practice. The findings of this study suggest that universities become leaders of future civilizations. Then, they must support students from all walks of life through the transition period from college to time in a sustainable society. In other words, a university with experience in improving the quality of prospective public leaders must be able to cooperate with many other universities; in terms of transfer of guidance between disciplinary programs; by making HR a central part of the entire institution; creating the preparation of prospective leaders on campus 
through the hands of reliable educators. This is in line with the findings. (Maier et al., 2015; Hifza et al., 2020; Hifza \& Aslan, 2020).

The almost similar idea comes from Mullen, (2010) who studied the 21st-Century priorities for leadership education and prospective school leaders. According to this study, instructors should plan understudies for professions, advanced education, citizenship, and worldwide availability, creators say. They said that future pioneers need to develop by teaming up with accomplices to work with change. Forefront innovations support educating and learning, they say, yet additionally, guarantee security for all. School authority requirements secured in a social equity epistemology can upgrade executive backing and obligation they compose. This article was initially distributed in the April 2013 issue of the magazine "Schools.

While Dwivedi \& Joshi, (2020) succeeded in studying initiatives pivotal to productivity enhancement, the 21st-Century of the Indian higher education system was. Excellent administration upgrades proficiency both in broad daylight and private area associations. The third biggest youth on the planet concentrating in higher education would contribute the most to developing 21st-century Indian economy and expectations for everyday comforts. This will be conceivable when the instructive efficiency of higher education administration is imaginatively changed into groundbreaking development. In this paper, impacts, outcomes, impacts, openings, issues, and cures regarding significant issues and difficulties for turning out to be elite training framework are deliberately checked on. Suggestions dependent on investigations and discoveries are made for 21st century higher education authority.

Then, the following evidence was from Thirkell \& Ashman, (2014). They lean towards getting the hang of interfacing Lean Thinking and human asset the executives in UK advanced education. As of late, endeavors have been made to move Lean standards and practice to the advanced education area. Regardless of human asset frameworks being essential aspects of Lean, human asset experts are barred from cooperation. This paper adds to the discussion by drawing proof from 34 meetings led across two UK colleges. The discoveries propose that there are issues in getting, imparting, and moving Lean thinking.

A similar leadership asset model came from Allui \& Sahni, (2016) with their vital human asset the executives in advanced education establishments: Empirical proof from Saudi. Saudi advanced education is dealing with serious issues encompassing human resources improvement, particularly of the staff. The representative enrollment and choice interaction is generally insufficient and needs successful consideration. Future examination ought to incorporate more colleges, both public and private, says the investigation. Likewise, it ought to consider directing factors, for example, college culture, association environment, and the work market, particularly with the Saudization (nationalization) of the workforce, lawful and administrative climate. The investigation contributes rich and decadent data for heads, workforce, and other advanced education faculty to apply and improve their accepted procedures in essential HR the executives, it says.

The finding from Madsen, (2012) prioritized ladies and initiative in advanced education through current fundamental factors, difficulties, and future bearings. This Issue investigates different points that straightforwardly impact the vocation choices, difficulties, encounters, and chances of ladies in postsecondary settings. The introduction article features the Issue's general Issue, reason, the methodology utilized, and importance to human asset advancement (HRD) and practice. Each article shares consequences of examination contemplates or sound systems and blueprints explicit 
ramifications for training. This Issue will give scientists and specialists in different fields of study with establishments and critical systems to be utilized for more intelligent instructing, examination, and practice around the subject of ladies and initiative.

Bolden et al., (2015) did the creating and supporting shared administration in advanced education. Shared administration moves the attention on authority from individual and position to measure. It is presently generally pushed across open, private, and not-revenue driven settings. Paper is focused on essentially at the center to senior-level academic and expert help supervisors. It looks to give down-to-earth direction to everyday initiative practice and advancement. The apparatuses, practices, and bits of knowledge in this report will help expose regular legends and misinterpretations about the shared initiative and offer a system retaliation. Introduction: This upgrade paper investigates how people and establishments can help create and support more comprehensive and shared authority societies and practices. The paper is organized into three principal parts - setting, practice, and commitment that consider, like this, the theoretical outlining, institutional practice, and personal and social change parts of the shared initiative. A broad scope of sources has been utilized to introduce assets and instances of utilizing a joint authority to accomplish change at numerous levels.

Another similar study was done by Middlehurst, (2013) through changing internal governance: with the question, Are leadership roles and management structures in United Kingdom Universities fit for the future public need?. This paper looks at changes and advancements in establishments' inward administration during the most recent decade, recognizing points of progression in the arrangement and world of politics in the United Kingdom just as points of contrast. Outside drivers are a feature of the inexorably powerful and unpredictable working conditions for advanced education. Foundations' inner administration plans are introduced inside a structure drawn from Clarke's investigations of enterprising colleges. The last part of the article contends for a retranslation and reinforcing of collegial types of administration, utilizing models and models drawn from imaginative private area organizations that can show helpful headings for advanced education foundations to be better fitted to address 21st-century difficulties. While the investigation is centered around the UK, the exercises are all the more generally pertinent.

Likewise, Au-Yong-Oliveira et al., (2018) successfully highlighted how the social effects of innovation on recent college graduates and the consequences for further education and administration. Their findings ask if recent college graduates are connected to innovation like the past, which affects how they need to be taught in further education. This investigation has an example of 111 millennial students discussing an overview of perspectives on administration. Future exploration should focus on how innovation has made society more straightforward, with workers in need of a fairer pioneer at a time when the chain of command is believed to be frustrating rather than aiding profitability levels. Investigate why the the researchers may be in the view of a dedicated millennial age, despite past research findings that have shown them to be sluggish.

Furthermore, Marcinkus Murphy, (2012) found that switching guidance at work encouraging cross-generational learning and creating millennial pioneers. According to him, that human resource management, Reverse tutoring includes a mix of younger, junior representatives go on as a guide to provide talent to more established senior colleagues as mentees. The goal is information sharing, with the mentee focused on 
acquiring the tutor's new subject or innovative skill. There is an emphasis on increasing the authority of tutors. A model was constructed centered around the key factors to consider and how to teach others and associations.

Effective leadership and excellence are currently indispensable for all public service organizations, including universities. Leaders can influence superiors and subordinates, but leadership in a broad context can also mean the ability and reliability in motivation for HR empowerment services with all the abilities and potential they have to achieve college goals, namely improving service quality outcomes of college graduates. To create competitive academics and a synergic culture of learning and teaching by all functional stakeholders are a must. The secret to effective leadership in higher education is that the greatest strength of a teacher and leader of each position is not only from his power but leads to his intelligence which has a positive impact on all academic communities who have strength in him / personality and transferred to service units, especially to students. Similar studies were also carried out.

Siemens et al., (2013) analyzed increasing quality and productivity in the higher education sector is relevant. Several publications the researchers have reviewed firmly confirm that these findings have answered our hypotheses and questions that want to seek evidence of research evidence on how to improve leadership in the rank-and-file of HR in tertiary institutions to achieve a competitive future. According to the paper, both structural and functional leaders in higher education can be seen from how to manage human resources or how lecturers transfer knowledge and their success in scientific works and community service. HR management can be done by empowering prospective alumni with higher HR learning outputs themselves. Learning outcomes result from guidance and dedication of the staff or power of campus and administrative staff, which, if appropriately managed, will have an impact on improving the quality of education they manage. (Musiige \& Maassen, 2015).

The contribution of this finding provide an understanding that higher education leaders must effectively manage human resources through teaching, researching, and serving the public with excellence. One of them is by empowering the academic community to improve the quality and quantity of the fields of duties and obligations of both lecturers and students. According to some papers, the fact is that in several universities, leaders are still overwhelmed in facing human resources that are difficult to develop and develop. This truth was also acknowledged by (Conn, 2013) where he said that turning on the light in a dark alley with educational leadership strategies for enhancing faculty research productivity and empowering students and society. The researchers have reviewed more than 50 publications that examine the importance of $\mathrm{HR}$ in improving the HR management function of a company. The findings have confirmed that HR empowerment has strategic reasons in increasing the efficiency of effective HR management for any company or organization. With the success of human resource empowerment, the company can balance the company's internal and competitiveness with its competitors (Ren \& Jackson, 2020). Every human resource study is of great benefit to improving company management, which can also assist the company in enhancing the positive contribution of its workforce so that the company can be profitable and sustainable.

\section{CONCLUSION}

The researchers emphasize that the purpose of this study is to find evidence of expert studies in improving human resources among universities in the future of the advanced era. In general, The researchers find that the leadership services of higher 
education are centered on the transfer of services in improving the quality of education output through teaching, both offline and online, according to the latest trends, research and scientific papers published and services to the community according to capacity and leadership. Based on the discussion of the findings and consideration of the evidence from previous studies, our study has answered questions and hypotheses qualitatively and descriptively. So with these findings, we hope that it will become a new input for improving higher education services for empowering human resource leadership in the 21st century in Indonesia in particular.

\section{ACKNOWLEDGEMENT}

The researchers would like to express our thanks to all of the colleagues for the support from the initial work until it is finished. Similar to my supervisors, who never endlessly provided feedback and correction. Without funding aid from our department, this project will not have been finished with the topic "What Expert Say about Empowering Human Resources in Supporting Leadership Function in Higher Education in the 21st Century".

\section{AUTHOR CONTRIBUTION STATEMENT}

The first author was greatly helped by the support of the second and third authors to support ideas since the planning period with problem formulation. In carrying out data search and analysis, The researchers can share parts of the work according to the agreement from the start. Even though they are coauthors, their contribution helped the first author. Here it is clear that The researchers are collaborative work and share authorship according to the initial agreement. Thank you for the participation and contribution.

\section{REFERENCES}

Allui, A., \& Sahni, J. (2016). Strategic human resource management in higher education institutions: Empirical evidence from Saudi. Procedia-Social and Behavioral Sciences, 235, 361-371.https:/ / doi.org/10.1177\%2F1326365X16640348

Aslan. (2017). Pumping Teacher dalam Tantangan Pendidikan Abad 21. Muallimuna, 2(2), 89-100. Google Scholar

Aslan, A., Silvia, S., Nugroho, B. S., Ramli, M., \& Rusiadi, R. (2020). Teacher's leadership teaching strategy supporting student learning during the covid-19 disruptioN. Nidhomul Haq: Jurnal Manajemen Pendidikan Islam, 5(3), 321333.https:// doi.org/10.31538/ndh.v5i3.984

Au-Yong-Oliveira, M., Gonçalves, R., Martins, J., \& Branco, F. (2018). The social impact of technology on millennials and consequences for higher education and leadership. Telematics and Informatics, 35(4), 954963.https:/ / doi.org/10.1016/j.tele.2017.10.007

Bafadal, I., Nurabadi, A., Sobri, A. Y., \& Gunawan, I. (2019). The Competence of Beginner Principals as Instructional Leaders in Primary Schools. International Journal of Innovation, Creativity and Change, 5(4), 625-639. Google Scholar

Bolden, R., Jones, S., Davis, H., \& Gentle, P. (2015). Developing and sustaining shared leadership in higher education. Google Scholar

Christensen, C. M., \& Eyring, H. J. (2011). The innovative university: Changing the DNA of higher education from the inside out. John Wiley \& Sons. Google Scholar

Churiyah, M., Sholikhan, S., Filianti, F., \& Sakdiyyah, D. A. (2020). Indonesia education readiness conducting distance learning in Covid-19 pandemic situation. 
What Expert Say about Empowering Human Resources in Supporting Leadership Function in Higher Education in the 21st Century

International Journal of Multicultural and Multireligious Understanding, 7(6), 491507.http://dx.doi.org/10.18415/ijmmu.v7i6.1833

Conley, V. M., \& Smith, K. J. (2013). Effectively managing human resources in 21stCentury Colleges and Universities. Organization and administration in higher education, 204-223. Google Scholar

Council, N. R. (2012). Education for life and work: Developing transferable knowledge and skills in the 21st century. National Academies Press. Google Scholar

Dwivedi, V. J., \& Joshi, Y. C. (2020). Leadership Pivotal to Productivity Enhancement for 21st-Century Indian Higher Education System. International Journal of Higher Education, 9(2), 126-143. Google Scholar

Fowler, S. (2018). Toward a new curriculum of leadership competencies: Advances in motivation science call for rethinking leadership development. Advances in Developing Human Resources, 20(2), 182196.https:// doi.org/10.1177\%2F1523422318756644

Garavan, T. N. (2007). A strategic perspective on human resource development. Advances in Developing Human Resources, 9(1), 1130.https:// doi.org/10.1177\%2F1523422306294492

Giambatista, R. C., Hoover, J. D., \& Tribble, L. (2017). Millennials, learning, and development: Managing complexity avoidance and narcissism. The PsychologistManager Journal, 20(3), 176.https:/ / psycnet.apa.org/doi/10.1037/mgr0000056

Hanapi, Z., \& Nordin, M. S. (2014). Unemployment among Malaysia graduates: Graduates' attributes, lecturers' competency and quality of education. ProcediaSocial and Behavioral Sciences, 112, 10561063.https://doi.org/10.1016/j.sbspro.2014.01.1269

Hifza \& Aslan. (2020). The Model of Competitive Advantage Development in Private Islamic Education Institutions dalam "BASA 2019: Proceedings of the Third International Seminar on Recent Language, Literature, and Local Culture Studies, BASA, 20-21 September 2019, Surakarta, Central Java, Indonesia. European Alliance for Innovation. Google Scholar

Hifza, Juliana, Palapa, A., Maskur, \& Aslan. (2020). The Strategic Foundation for Competitive Excellent Development in Integrated Islamic Primary Schools in Indonesia. International Journal of Advanced Science and Technology, 29(12s), 17471753. Google Scholar

Kakuma, R., Minas, H., Van Ginneken, N., Dal Poz, M. R., Desiraju, K., Morris, J. E., Saxena, S., \& Scheffler, R. M. (2011). Human resources for mental health care: Current situation and strategies for action. The Lancet, 378(9803), 16541663.https://doi.org/10.1016/S0140-6736(11)61093-3

Kementerian Hukum, H. A. M. Undang-Undang Republik Indonesia Nomor 12 Tahun 2012 Tentang Pendidikan Tinggi. Google Scholar

Kirkwood, A., \& Price, L. (2014). Technology-enhanced learning and teaching in higher education: What is 'enhanced'and how do we know? A critical literature review. Learning, media and technology, 39(1), 636.https:/ / doi.org/10.1080/17439884.2013.770404

Lestari, P. (2018). Sinkronisasi Pendidikan Pesantren dan Perguruan Tinggi Islam Guna Menyiapkan Sumber Daya Manusia Menyongsong Satu Abad Nahdlatul Ulama. Jurnal PROGRESS: Wahana Kreativitas dan Intelektualitas, 6(2), 140-169. Google Scholar 
What Expert Say about Empowering Human Resources in Supporting Leadership Function in Higher Education in the 21st Century

Lewin, C., \& McNicol, S. (2015). Supporting the development of 21st century skills through ICT. KEYCIT 2014: key competencies in informatics and ICT, 7, 181. Google Scholar

Lozano, R., Lukman, R., Lozano, F. J., Huisingh, D., \& Lambrechts, W. (2013). Declarations for sustainability in higher education: Becoming better leaders, through addressing the university system. Journal of Cleaner Production, 48, 1019.https:// doi.org/10.1016/j.jclepro.2011.10.006

Madsen, S. R. (2012). Women and leadership in higher education: Current realities, challenges, and future directions. Advances in Developing Human Resources, 14(2), 131-139.https:/ / doi.org/10.1177\%2F1523422311436299

Maier, T., Tavanti, M., Bombard, P., Gentile, M., \& Bradford, B. (2015). Millennial generation perceptions of value-centered leadership principles. Journal of Human Resources in Hospitality $\mathcal{E}$ Tourism, 14(4), 382397.https://doi.org/10.1080/15332845.2015.1008386

Malik, K. (2013). Human development report 2013. The rise of the South: Human progress in a diverse world. The Rise of the South: Human Progress in a Diverse World (March 15, 2013). UNDP-HDRO Human Development Reports. Google Scholar

Marcinkus Murphy, W. (2012). Reverse mentoring at work: Fostering crossgenerational learning and developing millennial leaders. Human Resource Management, 51(4), 549-573.https://doi.org/10.1002/hrm.21489

Middlehurst, R. (2013). Changing Internal Governance: Are Leadership Roles and Management Structures in U nited K ingdom Universities Fit for the Future? Higher Education Quarterly, 67(3), 275-294.https:/ / doi.org/10.1111/hequ.12018

Mullen, C. A. (2010). 21st-Century Priorities for Leadership Education and Prospective School Leaders. Scholar-Practitioner Quarterly, 4(4), 331-333. Google Scholar

Musiige, G., \& Maassen, P. (2015). Faculty perceptions of the factors that influence research productivity at Makerere University. Knowledge production and contradictory functions in African higher education, 109-127. Google Scholar

Norton, M. S. (2008). Human Resources Administration for Educational Leaders: SAGE Publications. Sage Publications. Google Scholar

Pazli, P., \& Sahputra, A. (2014). Peran Unesco Dalam Pemberantasan Buta Aksara Di Indonesia Tahun 2007-2012 [PhD Thesis]. Riau University. Google Scholar

Pieper, R. (2012). Human resource management: An international comparison (Vol. 26). Walter de Gruyter. Google Scholar

Ren, S., \& Jackson, S. E. (2020). HRM institutional entrepreneurship for sustainable business organizations. Human Resource Management Review, 30(3), 100691.https:/ / doi.org/10.1016/j.hrmr.2019.100691

Riddell, A., \& Niño-Zarazúa, M. (2016). The effectiveness of foreign aid to education: What can be learned? International Journal of Educational Development, 48, 23-36. Google Scholar

Sewell, C., \& Kingsley, D. (2017). Developing the 21st century academic librarian: The Research Support Ambassador Programme. New Review of Academic Librarianship, 23(2-3), 148-158.https:/ / doi.org/10.1080/13614533.2017.1323766

Siemens, G., Dawson, S., \& Lynch, G. (2013). Improving the quality and productivity of the higher education sector. Policy and Strategy for Systems-Level Deployment of Learning Analytics. Canberra, Australia: Society for Learning Analytics Research for the Australian Office for Learning and Teaching, 31. Google Scholar 
What Expert Say about Empowering Human Resources in Supporting Leadership Function in Higher Education in the 21st Century

Steiner, L. (2010). Using Competency-Based Evaluation to Drive Teacher Excellence: Lessons from Singapore. Building an Opportunity Culture for America's Teachers. Public Impact. Google Scholar

Tanang, H., \& Abu, B. (2014). Teacher Professionalism and Professional Development Practices in South Sulawesi, Indonesia. Journal of curriculum and teaching, 3(2), 25-42. Google Scholar

Thirkell, E., \& Ashman, I. (2014). Lean towards learning: Connecting Lean Thinking and human resource management in UK higher education. The International Journal of Human Resource Management, 25(21), 29572977.https:/ / doi.org/10.1080/09585192.2014.948901

Thomas, V. K., Satpathi, C., \& Satpathi, J. N. (2010). Emerging challenges in academic librarianship and role of library associations in professional updating. Library Management.https:// doi.org/10.1108/01435121011093379

Tyas, E. H., Sunarto, S., \& Naibaho, L. (2020). Building Superior Human Resources through Character Education. TEST Engineering \& Management, 83, 1186411873. Google Scholar

Undang-Undang Republik Indonesia. (2012). Tahun 2012 tentang Pendidikan Tinggi.

Wächter, H. (1991). Human Resource Management: An International Comparison. JSTOR. Google Scholar

White, J. S. (2012). HERS institutes: Curriculum for advancing women leaders in higher education. Advances in Developing Human Resources, 14(1), 1127.https://doi.org/10.1016/j.sbspro.2016.11.044

\section{Copyright Holder :}

(C) Hermawan, E., \& Arifin, A., (2021).

First Publication Right :

(C) Jurnal Iqra' : Kajian Ilmu Pendidikan

This article is under

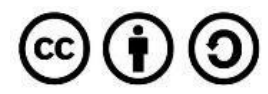

